\title{
Pengelolaan Daerah Tangkapan Air Waduk Pembangkit Listrik Tenaga Air (PLTA) Koto Panjang Berkelanjutan
}

\section{Sustainable Management of Catchment areas of the Koto Panjang Hydroelectric Reservoir}

\author{
Aan Nur Rahmat ${ }^{1 *}$, Mubarak ${ }^{2}$, dan Ridwan Manda Putra ${ }^{2}$ \\ ${ }^{\prime}$ Mahasiswa Program Magister Ilmu Lingkungan Universitas Riau \\ ${ }^{2}$ Dosen Program Magister Ilmu Lingkungan Universitas Riau \\ *Email: aan.rahmat82@gmail.com
}

\begin{abstract}
Abstrak
Diterima

Provinsi Riau memiliki banyak danau dan waduk, salah satunya adalah Waduk

27 Februari 2020

PLTA Koto Panjang. Kontinuitas air yang tidak stabil, kekeringan selama musim kemarau dan banjir saat musim hujan menyebabkan pembangkit listrik ini tidak optimal, salah satu cara yang bisa dilakukan untuk mengatasi komplikasi di area tertentu. Air Waduk PLTA Koto Panjang adalah bahwa dengan menggunakan

Disetujui

17 Mei 2020 analisis Waduk PLTA Koto Panjang kita dapat mengatur langkah-langkah dalam mengelola pemeliharaan Waduk PLTA Koto Panjang. Analisis keberlanjutan dilakukan dengan menggunakan aplikasi RAP-daerah tangkapan air pada tiga dimensi, yaitu ekologi, ekonomi dan sosial, hasil analisis yang telah dilakukan pada dimensi ekologis membahas indeks 52,31 yang tergolong cukup berkelanjutan dalam dimensi sosial kategori 41,98 yang digolongkan kurang berkelanjutan. Untuk meningkatkan indeks keberlanjutan dalam pengelolaan wilayah perairan, diperlukan beberapa arahan pengelolaan, yaitu reboisasi atau penghijauan lahan terbuka terkait sungai dan melakukan pelatihan pertanian ramah lingkungan untuk menyediakan dan mendukung perlindungan komoditas pertanian dan masyarakat terkait kebakaran, mengembangkan potensi sumber daya alam seperti tempat wisata sebagai mata pencaharian alternatif untuk meningkatkan pendapatan masyarakat dan meningkatkan sosialisasi dan mendorong orang yang membutuhkan di daerah tangkapan air waduk PLTA
\end{abstract}

Kata kunci: keberlanjutan, RAP-Daerah tangkapan air, Wilayah tangkapan air

\section{Abstract}

Riau Province has many lakes and reservoirs, one of which is the Koto Panjang Hydroelectric Reservoir, Sustainability of the Koto Panjang Hydroelectric Reservoir Unstable water continuity, drought during the dry season and flooding during the rainy season have caused this power plant to be not optimal, one of the ways that can done to overcome complications in certain areas. Koto Panjang Hydroelectric Reservoir Water is that by using the analysis of the Koto Panjang Hydroelectric Reservoir we can arrange steps in managing the maintenance of the Koto Panjang Hydroelectric Reservoir. Sustainability analysis conducted using the RAP-catchment area application on three dimensions, namely ecology, economics and social, the results of the analysis that have been carried out on the ecological dimension address an index of $\mathbf{5 2 . 3 1}$ which is classified as quite sustainable in the social dimension category 41.98 which is classified as less sustainable. To improve the index of sustainability in the management of water areas, several management directives are needed, namely reforestation or greening of open land related to rivers and conducting training in environmentally friendly agriculture to provide and support the protection of farming communities and communities related to fire, develop the potential of natural resources such as tourist attractions 
as alternative livelihoods to increase community income and increase socialization and encourage people in need in hydropower reservoir catchment areas.

Keyword: sustainability, RAP-Catchment area, Catchment area

\section{Pendahuluan}

Indonesia memiliki kekayaan sumber daya alam yang sangat besar, salah satunya adalah ekosistem danau. Indonesia memiliki \pm 840 danau besar dan kecil yang terdiri dari danau vulkanik dan danau tektonik, tipologi danau di Indonesia sangat bervariasi dan sebagian besar danau di Indonesia merupakan danau alami. Secara umum kondisi danau di Indonesia terus mengalami penurunan kualitas dan kuantitas, beberapa danau yang telah mengalami penurunan kualitas diantaranya adalah Danau Toba, Danau Maninjau, Danau Rawapening, Danau Limboto. Beberapa faktor yang menyebabkan terjadinya penurunan kualitas danau adalah adanya pemanfaatan sumber daya alam yang berlebihan tanpa mempertimbangkan kaidah-kaidah konservasi.

Provinsi Riau memiliki banyak danau dan waduk, salah satunya adalah waduk PLTA Koto Panjang, ekosistem waduk PLTA Koto Panjang merupakan kesatuan dimensi dari DTA, Perairan hingga sosial ekonomi masyarakat. Waduk PLTA Koto Panjang memiliki peran penting bagi masyarakat yang berada di sekitarnya, sebagian besar masyarakat memanfaatkan ekosistem waduk guna memenuhi kebutuhan hidup.

Daerah tangkapan air (DTA) yang terdapat di PLTA Koto Panjang berasal dari Provinsi Sumatera Barat dan Provinsi Riau. Waduk ini mendapat pasokan air utama dari Sungai Kampar dan Sungai Batang Mangat yang berhulu di provinsi Sumatera Barat (PLN dalam Siagian, 2010). Daerah tangkapan air merupakan suatu wilayah yang memberikan pengaruh besar terhadap ketersediaan air suatu daerah. Keberlangsungan waduk PLTA Koto Panjang sangat ditentukan oleh sumber air yang bergantung pada DTA, yang mana kondisi DTA saat ini sudah mengalami tekanan yang cukup besar. Tekanan utama yang menjadi faktor penurunan kualitas DTA adalah alih fungsi lahan untuk kegiatan ekonomi dan pembukaan lahan yang tidak terkontrol sehingga mengancam fungsi dari DTA. Pengelolaan daerah tangkapan air perlu dilakukan untuk menjaga kelangsungan waduk PLTA Koto panjang serta mendukung pembangunan yang berkelanjutan.

Keberlanjutan waduk PLTA Koto Panjang menghadapi permasalahan yang amat serius beberapa tahun terakhir. Kontinuitas air yang tidak stabil, kekeringan pada saat musim kemarau dan banjir pada musim hujan telah menyebabkan pembangkit listrik tersebut tidak berfungsi secara optimal. Fenomena ini disebabkan oleh dua faktor utama, yaitu (1) faktor manusia, aktivitas antropogenik yang bersifat destruktif; (2) faktor alam, seperti tingginya presipitasi. Kondisi tersebut pada akhirnya secara simultan menimbulkan tekanan dalam dimensi ekologis, sosial, dan ekonomi sehingga mengancam fungsi DTA.

Salah satu cara yang dapat dilakukan untuk mengetahui permasalahan secara jelas pada daerah DTA Waduk PLTA Koto Panjang adalah dengan melakukan analisis keberlanjutan pada aspek ekologi, ekonomi dan sosial dengan mengetahui permasalahan utama pada DTA Waduk PLTA Koto Panjang kita dapat menyusun langkahlangkah dalam melakukan pengelolaan Waduk PLTA Koto Panjang berkelanjutan.

\section{Bahan dan Metode}

\subsection{Metode Penelitian}

Penelitian ini merupakan penelitian kuantitatif dengan menggunakan metode survei untuk melihat keberlanjutan daerah tangkapan air waduk PLTA Koto Panjang. Penelitian ini dilaksanakan di Desa Siberuang, Tanjung dan Muara Takus Kabupaten Kampar Kecamatan Koto Kampar Hulu dan XIII Koto Kampar

Kabupaten Kampar Provinsi Riau. Penelitian akan dilaksanakan pada bulan Agustus 2019 - Januari 2020. Alat yang digunakan dalam penelitian ini adalah laptop, alat tulis, kuesioner, kamera dan aplikasi Rapfish.

\section{Hasil dan Pembahasan}

Daerah Tangkapan Air waduk PLTA Koto Panjang terletak di dua wilayah administrasi, yaitu Kabupaten Kampar, Provinsi Riau dengan luas 72.088,96 ha (21,89\%), dan wilayah administrasi Provinsi Sumatera Barat dengan luas 257.256,81 ha (78,11\%) dengan rincian dalam Kabupaten Pasaman 54.757,04 ha (16,63\%) dan Kabupaten Lima Puluh Kota 202.499,77 ha (61,49\%) (Nurdin et al, 2017). 
Untuk mengetahui kondisi ekologi, ekonomi dan sosial masyarakat berada pada daerah tangkapan air Waduk PLTA Koto Panjang dilakukan dengan menggunakan metode wawancara, berdasarkan hasil wawancara terhadap kondisi ekologi diketahui masih terdapat kegiatan alih fungsi lahan, illegal logging dan sistem permbersihan lahan dengan cara dibakar. Alih fungsi lahan atau deforestasi memberikan dampak terhadap kerusakan lahan dan kemampuan DAS dalam meresap air (Heryani, 2012). hal ini akan memberikan dampak negatif terhadap keberlanjutan DTA Waduk PLTA Koto panjang, akan tetapi pada lokasi penelitian terdapat hutan adat dan kegiatan reboisasi atau penghijauan yang memberikan dampak positif terhadap keberlanjutan daerah tangkapan air.

Berdasarkan hasil wawancara masyarakat yang telah dilakukan terhadap kondisi ekonomi pada lokasi penelitian diketahui jumlah penduduk miskin tergolong sedikit, akan tetapi sebagian besar penduduk memiliki penghasilan dibawah UMR/UMK yang telah ditetapkan oleh Kabupaten Kampar, selain itu masih terdapat aktivitas masyarakat yang memanfaatkan kayu dan hasil hutan bukan kayu untuk meningkatkan penghasilan, hal ini akan berdampak buruk terhadap kelangsungan DTA Waduk PLTA Koto Panjang sehingga perlu dilakukan pengelolaan untuk meningkatkan penghasilan masyarakat.

Kondisi sosial pada lokasi penelitian menunjukan sebagian besar responden SMP-SMA dan sebagian masyarakat pada lokasi penelitian tidak mengetahui daerah tangkapan air hal, ini akan berdampak terhadap peran serta dalam memelihara DTA menjadi rendah.

Penentuan status berkelanjutan daerah tangkapan air waduk PLTA Koto Panjang dilakukan dengan menggunakan metode RAP-Catchment area. Analisis ini dilakukan dengan cara memberikan penilaian terhadap setiap atribut dari masing-masing dimensi pada penelitian. Status keberlanjutan diwakili oleh besar kecilnya kisaran nilai yang dihasilkan dalam ordinasi RAP-Catchment area pada setiap dimensi. Berdasarkan hasil analisis RAP-Catchment area yang telah dilakukan terhadap atribut-atribut pada dimensi ekologi menunjukkan bahwa indeks keberlanjutan dimensi ekologi pada daerah tangkapan air waduk PLTA Koto Panjang tergolong kedalam kategori cukup berkelanjutan. Untuk melihat hasil analisis RAP-Catchment area yang telah dilakukan dapat dilihat pada Gambar 1.

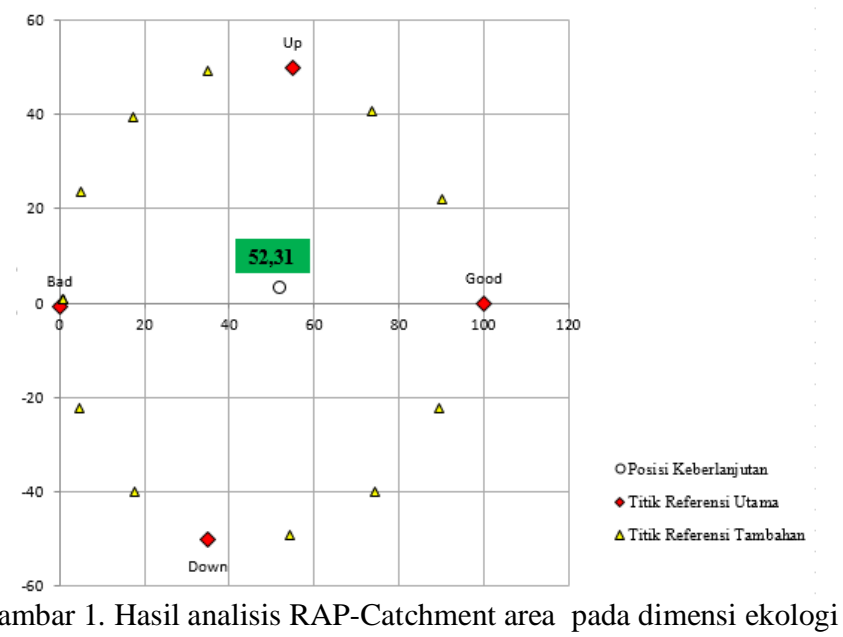

Berdasarkan hasil analisis keberlanjutan yang telah dilakukan diatas dapat dilihat indeks keberlanjutan pada dimensi ekologi tergolong dalam kategori cukup berkelanjutan dengan indeks 52,31, dimana nilai indeks 50-75 tergolong dalam kategori cukup berkelanjutan. Cukup berlanjutnya pengelolaan pada dimensi ekologi menunjukan kondisi lingkungan khususnya ekologi masih dalam keadaan baik dan masih bisa mendukung keberlanjutan dari DTA Waduk PLTA Koto Panjang, meskipun demikian pengelolaan terhadap dimensi ekologi tetap harus dilakukan untuk mempertahankan status keberlanjutannya.

Analisis leverage dilakukan untuk melihat atribut-atribut sensitif pada dimensi ekologi yang mempengaruhi indeks keberlanjutan. Untuk melihat hasil analisis leverage pada dimensi ekologi dapat dilihat pada Gambar 2. 


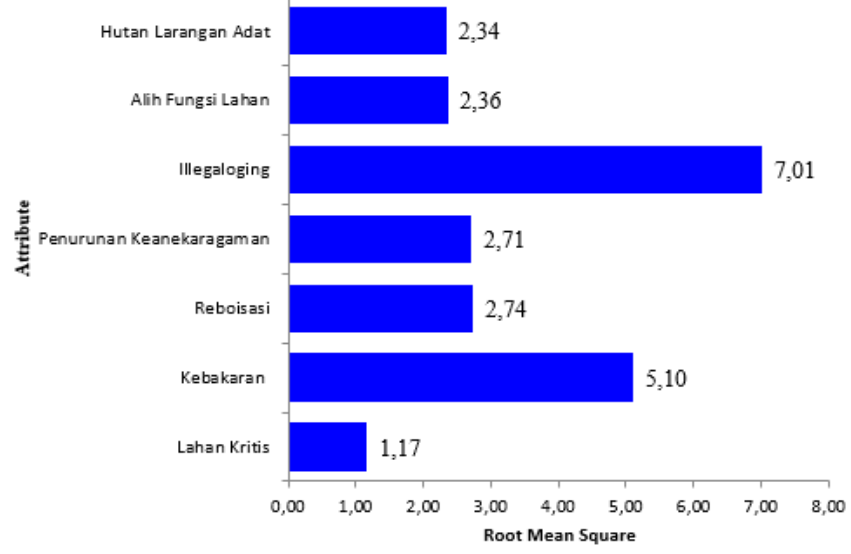

Gambar 2. Hasil analisis leverage pada dimensi ekologi

Berdasarkan hasil analisis leverage pada dimensi ekologi dapat dilihat terdapat dua atribut yang tergolong sensitif jika dibandingkan dengan atribut yang lainnya yaitu illegal logging dan kebakaran. Meskipun dari wawancara yang telah dilakukan kejadian illegal logging dan kebakaran hutan dan lahan cenderung memiliki persentase yang kecil akan tetapi kegiatan ini memberikan dampak yang besar terhadap peningkatan luasan lahan kritis pada lokasi penelitian dan mengancam keberlanjutan daerah tangkapan air. Menurut Ardhana (2016), kerusakan hutan yang terjadi dapat memicu terjadinya kebakaran hutan dan lahan. Untuk mewujudkan pengelolaan yang berkelanjutan pada DTA Waduk PLTA Koto Panjang perlu diperhatikan atribut-atribut yang memiliki nilai sensitivitas tinggi, diperlukan arahan pengelolaan terutama pada aspek illegal logging dan kebakaran agar DTA Waduk PLTA Koto Panjang bisa berkelanjutan.

Dimensi ekonomi juga merupakan salah satu dimensi yang memiliki pengaruh terhadap keberlanjutan Daerah Tangkapan Air Waduk PLTA Koto Panjang. keberadaan aktivitas ekonomi masyarakat yang berada pada lokasi penelitian dapat mempengaruhi kondisi daerah tangkapan air baik memberikan dampak yang positif maupun dampak negatif. Berdasarkan hasil analisis RAP-Catchment area yang telah dilakukan terhadap dimensi ekonomi menunjukkan indeks tergolong dalam kategori kurang berkelanjutan dengan nilai 39,26. Untuk melihat hasil analisis secara rinci dapat dilihat pada Gambar 3.

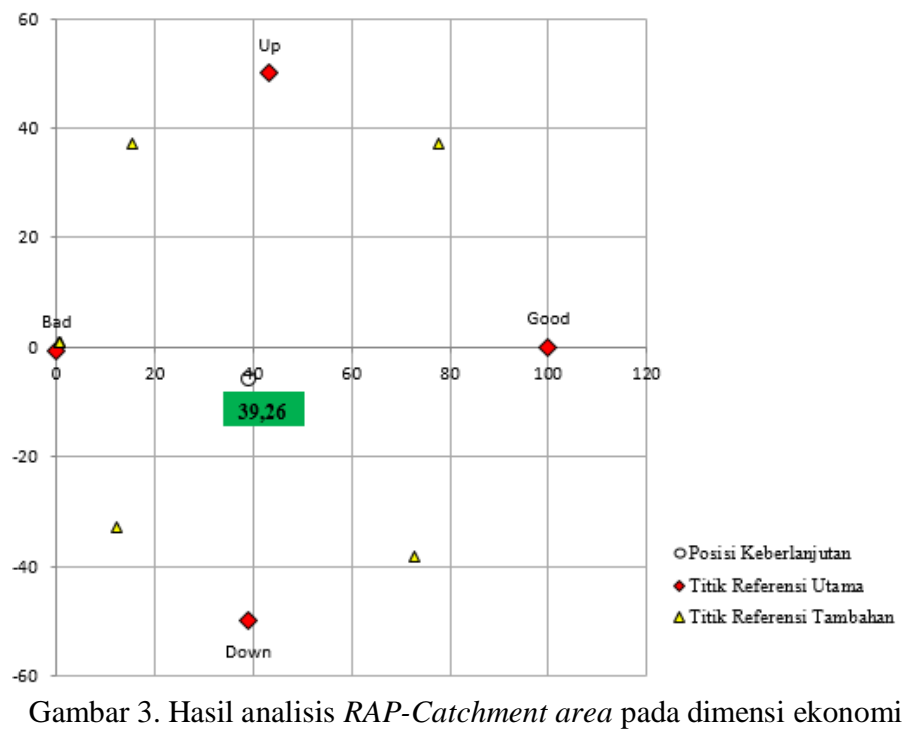

Dari hasil analisis leverage pada dimensi ekonomi yang telah dilakukan dapat dilihat terdapat atribut yang memiliki sensitivitas yang cukup tinggi jika dilihat dari beberapa atribut lainnya, atribut yang memiliki sensitivitas tinggi pada dimensi ekonomi yaitu pendapatan masyarakat. Untuk melihat hasil analisis leverage yang telah dilakukan terhadap dimensi ekonomi dapat dilihat pada Gambar 4. 


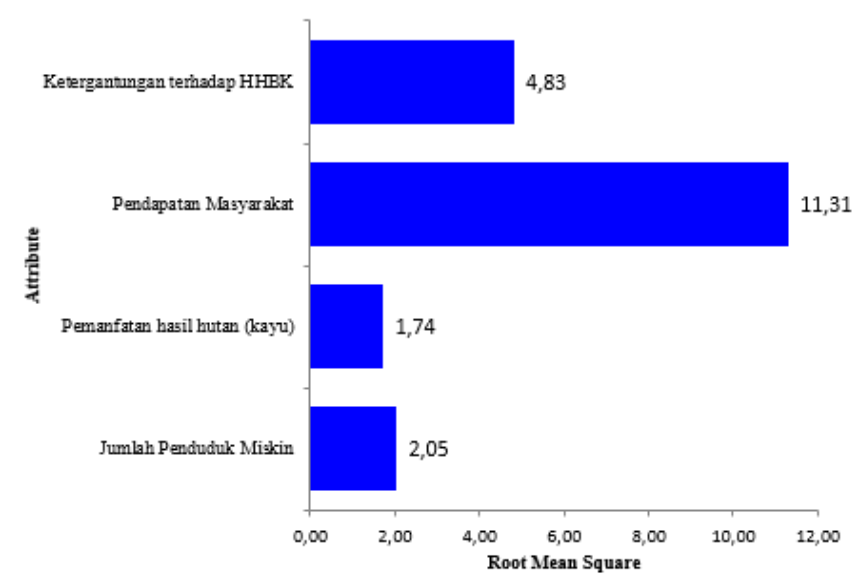

Gambar 4. Hasil analisis leverage pada dimensi ekonomi

Gambar 4 dapat dilihat sensitivitas tertinggi terdapat pada atribut pendapatan masyarakat, sebagian besar masyarakat yang berada di daerah tangkapan air waduk PLTA koto panjang pada lokasi penelitian berprofesi sebagai petani. Perlu dilakukan pengembangan mata pencaharian alternatif lain untuk meningkatkan penghasilan masyarakat salah satunya adalah pengembangan ekowisata pada kawasan air terjun yang terdapat di lokasi penelitian khususnya Desa Tanjung dapat memberikan penghasilan alternatif untuk meningkat perekonomian masyarakat pada lokasi penelitian, dengan adanya mata pencaharian alternatif diharapkan dapat menurunkan pemanfaatan sumber daya alam seperti kayu dan kegiatan illegal logging serta menurunkan tingkat kemiskinan pada lokasi penelitian, dengan demikian pengelolaan DTA Waduk PLTA Koto Panjang dapat berkelanjutan.

Dimensi sosial merupakan dimensi yang menggambarkan kondisi yang berkaitan dengan kehidupan masyarakat sekitar yang berada di lokasi penelitian. Atribut-atribut pada dimensi sosial menggambarkan bagaimana masyarakat dalam melakukan pemanfaatan pada daerah tangkapan air waduk PLTA Koto Panjang. berdasarkan hasil analisis RAP-Catchment area yang telah dilakukan pada dimensi sosial menunjukkan kondisi kurang berkelanjutan dengan indeks 41,98 , sementara nilai indeks yang menunjukan cukup berkelanjutan adalah 50-75 dan berkelanjutan 75-100. Untuk meningkatkan keberlanjutan pada dimensi sosial perlu dilakukan berbagai upaya pengelolaan, pengelolaan yang dilakukan berdasarkan tingkat sensitivitas dari masing-masing atribut yang dianalisis pada dimensi sosial. Untuk melihat secara rinci hasil analisis RAP-Catchment area terhadap dimensi sosial dapat dilihat pada Gambar 5.

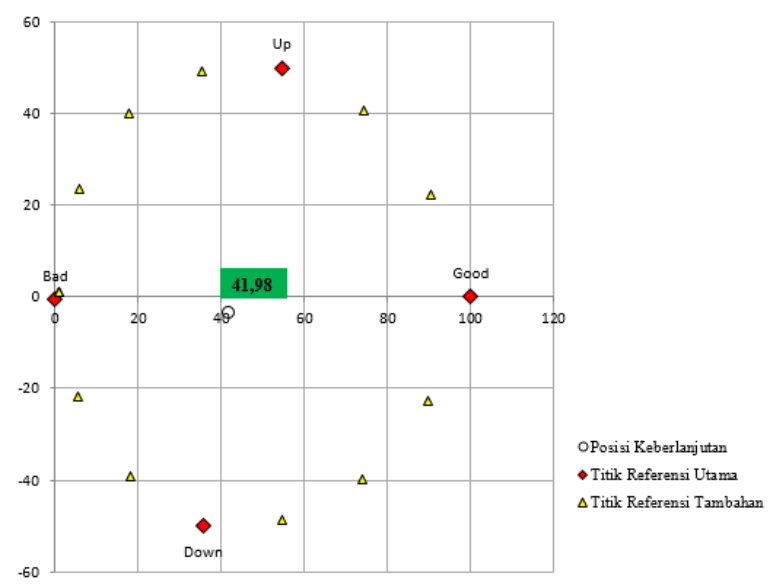

Gambar 5. Hasil analisis RAP-Catchment area pada dimensi sosial

Berdasarkan hasil analisis leverage terhadap atribut dimensi sosial terdapat satu atribut yang memiliki sensitivitas lebih tinggi yang mempengaruhi nilai indeks keberlanjutan yaitu pengetahuan masyarakat terhadap DTA. Untuk melihat hasil analisis leverage secara rinci terhadap masing-masing atribut pada dimensi sosial dapat dilihat pada Gambar 6. 


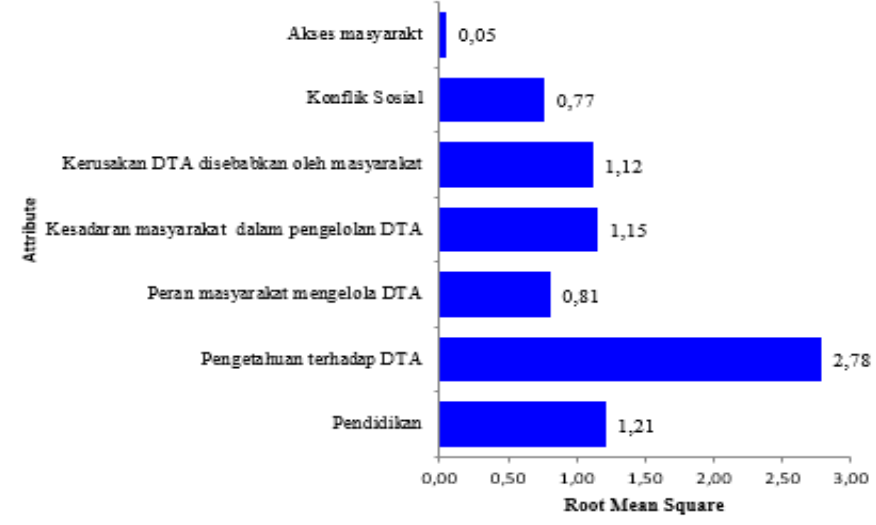

Gambar 6. Hasil analisis leverage pada dimensi sosial

Gambar 6 dapat dilihat atribut yang memiliki sensitifitas terbesar yaitu tingkat pengetahuan masyarakat terhadap keberadaan daerah tangkapan air. Berdasarkan hasil wawancara yang telah dilakukan terhadap tingkat pengetahuan masyarakat terhadap DTA tergolong rendah hal ini dapat dilihat dari hasil analisis yang menunjukan sebanyak 57,8\% responden tidak mengerti dengan daerah tangkapan air yang ada disekitarnya. Rendahnya pengetahuan masyarakat disebabkan oleh tidak adanya sosialisasi serta pemahaman dan keterlibatan masyarakat dalam mengelola daerah tangkapan air tersebut, selain itu tidak adanya kepentingan masyarakat terhadap daerah tangkapan air menyebabkan partisipasi masyarakat dalam mengelola dan menjaga menjadi rendah. Peningkatan pengetahuan masyarakat terhadap DTA pada lokasi penelitian harus ditingkatkan agar kesadaran masyarakat dalam mengelola daerah tangkapan air juga mengalami peningkatan sehingga kerusakan DTA yang disebabkan oleh masyarakat dapat diminimalisir, dengan demikian pengelolaan DTA Waduk PLTA Koto Panjang dapat berjalan dengan baik. Bentuk partisipasi masyarakat dapat berupa kontribusi tenaga, pikiran, waktu dan dana yang dicurahkan dalam perencanaan, pelaksanaan dan pengawasan kegiatan pengelolaan/ pelestarian lingkungan (Gumilar, 2012).

Analisis keberlanjutan multidimensional dilakukan dengan cara menggabungkan seluruh dimensi yaitu dimensi ekologi, ekonomi dan sosial. Hasil analisis keberlanjutan multidimensional menunjukkan indeks sebesar 44,07 yang tergolong dalam kategori kurang berkelanjutan. Untuk melihat hasil analisis keberlanjutan multidimensional secara rinci dapat dilihat pada Gambar 7.

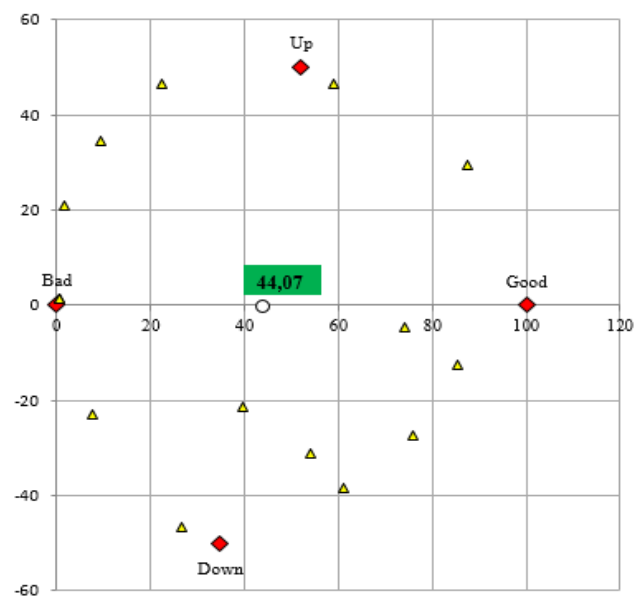

OPosisi Keberlanjutan

- Titik Referensi Utama

$\Delta$ Titik Referensi Tambahan

Gambar 7. Hasil analisis RAP-Catchment area Multidimensi pengelolaan daerah tangkapan air waduk PLTA Koto Panjang

Hasil analisis RAP-Catchment area multidimensi menunjukkan indeks yang tergolong dalam kategori kurang berkelanjutan, rendahnya indeks multidimensional pengelolaan DTA Waduk PLTA Koto Panjang disebabkan terdapat dua dimensi yang tergolong dalam kategori kurang berkelanjutan yaitu dimensi ekonomi dan dimensi sosial, hanya terdapat satu dimensi yang tergolong dalam kategori cukup berkelanjutan yaitu dimensi ekologi. Untuk meningkatkan indeks keberlanjutan multidimensi pengelolaan DTA Waduk PLTA Koto Panjang perlu dilakukan pengelolaan terutama pada dimensi ekonomi dan ekologi, akan tetapi pengelolaan pada dimensi ekologi tetap dipertahankan dan ditingkatkan. Untuk melihat hasil analisis keberlanjutan pada masingmasing dimensi dapat dilihat pada Gambar 8. 


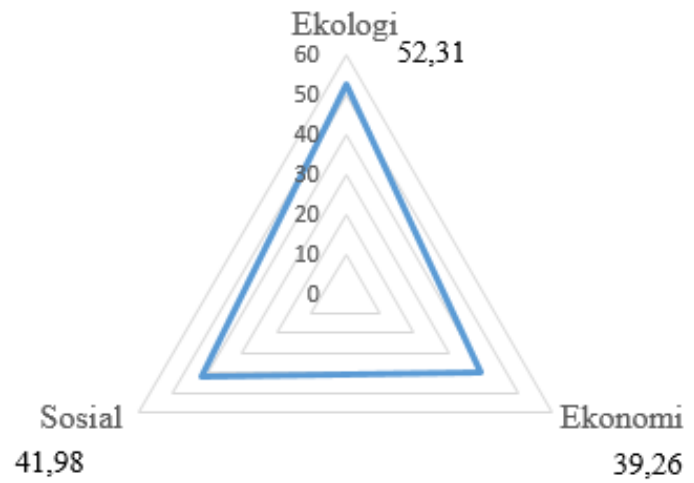

Gambar 8. Diagram indeks keberlanjutan pengelolaan daerah tangkapan air waduk PLTA Koto Panjang

Berdasarkan hasil analisis indeks keberlanjutan yang telah dilakukan dapat dilihat pada dimensi ekologi tergolong dalam kategori cukup berkelanjutan dengan indeks 52,31, sedangkan pada dimensi sosial $(41,98)$ dan ekonomi $(39,26)$ tergolong dalam kategori kurang berkelanjutan. Berdasarkan kriteria indeks keberlanjutan terbagi kedalam 4 kategori yaitu 0-25 tergolong kedalam kategori tidak berkelanjutan, 26-50 kurang berkelanjutan, 51-75 cukup berkelanjutan dan 76-100 tergolong dalam kategori berkelanjutan. Berdasarkan Gambar 8 diatas dapat dilihat dalam pengelolaan DTA Waduk PLTA Koto Panjang saat ini masih memprioritaskan dari aspek ekologi saja, perlu dilakukan peningkatan pengelolaan pada aspek ekonomi dan sosial sehingga pengelolaan keberlanjutan DTA Waduk PLTA Koto panjang dapat berjalan dengan baik.

Uji validitas dilakukan dengan cara membandingkan antara hasil analisis MDS dan analisis Monte Carlo dengan taraf kepercayaan $95 \%$. Berdasarkan hasil analisis yang telah dilakukan menunjukan selisih yang relatif kecil, Perbedaan nilai yang sangat kecil ini menunjukkan bahwa kesalahan dalam proses analisis dapat diperkecil atau dihindari. Kesalahan yang disebabkan pemberian skoring pada setiap atribut, variasi pemberian skoring yang bersifat multidimensi karena adanya opini yang berbeda relatif kecil, proses analisis data yang dilakukan secara berulang-ulang relatif stabil, dan kesalahan dalam melakukan input data dan data yang hilang dapat dihindari (Fauzi et al, 2005 diacu dalam Adimu, 2018). untuk melihat hasil analisis MDS dan Monte Carlo dapat dilihat pada Tabel 1.

Tabel 1. Perbandingan nilai indeks keberlanjutan pada analisis MDS dan analisis Monte Carlo

\begin{tabular}{clccc}
\hline No & & Dimensi & Nilai MDS & Monte Carlo \\
\hline 1 & Ekologi & 52,31 & 51,37 \\
2 & Ekonomi & 39,26 & 39,63 \\
3 & Sosial & 41,98 & 42,26 \\
\hline
\end{tabular}

Berdasarkan Tabel 1 dapat dilihat perbandingan hasil analisis indeks keberlanjutan pada MDS dan Monte carlo menunjukan tidak bahwa tidak ada perbedaan yang cukup besar antara MDS dan Monte Carlo, kecilnya selisih atau perbedaan pada indeks MDS dan Monte Carlo menunjukan bahwa kesalahan dalam dalam pembuatan skala relatif kecil.

Hasil dari ordinasi RAP-Catchment area untuk setiap dimensi menunjukan nilai stress berkisar antara 0,13 0,15 yang tergolong dalam kategori baik, hal ini disebabkan oleh nilai stress masih $<0,25$. Nilai koefisien determinasi $\left(\mathrm{R}^{2}\right)$ yang diperoleh menjelaskan bahwa model peubah yang digunakan sudah dapat menjelas kan 94-95\% dari model yang ada, nilai $\mathrm{R}^{2}$ pada penelitian ini tergolong dalam kategori yang baik dan tidak terjadi kesalahan dalam melakukan analisis. Menurut Kavanagh (2001) diacu dalam Noveliyana (2016) nilai koefisien determinasi $\left(\mathrm{R}^{2}\right)$ tergolong dalam kategori baik apabila berada dalam rentang $80 \%$ hingga $100 \%$. Untuk melihat secara rinci nilai statistik analisis RAP-Catchment area pada masing-masing dimensi dapat dilihat pada Tabel 2.

Tabel 2. Nilai statistik hasil analisis RAP-Catchment area pada masing-masing dimensi dalam pengelolaan daerah tangkapan air waduk PLTA Koto Panjang

\begin{tabular}{|c|c|c|c|}
\hline \multirow{2}{*}{ No } & \multirow{2}{*}{ Dimensi } & \multicolumn{2}{|c|}{ Nilai Statistik } \\
\hline & & Stress & R2 (\%) \\
\hline 1 & Ekologi & 0,13 & 94 \\
\hline 2 & Ekonomi & 0,13 & 95 \\
\hline 3 & Sosial & 0,15 & 94 \\
\hline
\end{tabular}




\section{Kesimpulan}

Berdasarkan hasil analisis data penelitian yang telah dilakukan dapat disimpulkan bahwa:

1. Kondisi ekologi, ekonomi dan sosial masyarakat pada lokasi penelitian secara tidak langsung memberikan dampak positif dan negatif terhadap keberlanjutan daerah tangkapan air Waduk PLTA Koto Panjang.

a) kondisi ekologi Pada lokasi penelitian menunjukkan masih dijumpai adanya kegiatan aktivitas alih fungsi lahan, illegal logging dan sistem pembersihan lahan dengan cara dibakar, hal ini berdampak negatif terhadap keberlanjutan daerah tangkapan air, akan tetapi pada lokasi penelitian terdapat hutan larangan adat dan kegiatan penghijauan.

b) Kondisi ekonomi pada lokasi penelitian menunjukan jumlah penduduk miskin tergolong sedikit, akan tetapi sebagian besar masyarakat memiliki penghasilan dibawah UMK/UMR Kabupaten Kampar, selain itu masih terdapat aktivitas masyarakat yang memanfaatkan kayu dan hasil hutan bukan kayu untuk memenuhi kebutuhan hidup sehari-hari.

c) Kondisi Sosial pada lokasi penelitian menunjukkan sebagian besar responden berpendidikan SMPSMA, sebagian besar masyarakat tidak mengetahui daerah tangkapan air sehingga peran serta masyarakat dalam mengelola daerah tangkapan air tergolong dalam kategori sedang.

2. Berdasarkan hasil analisis status keberlanjutan daerah tangkapan air waduk PLTA Koto Panjang pada lokasi penelitian tergolong dalam kategori kurang berkelanjutan dengan indeks 44,07. Indeks keberlanjutan pada dimensi ekologi yaitu 52,31 yang tergolong dalam kategori cukup berkelanjutan, sedangkan indeks indeks pada dimensi ekonomi dan sosial tergolong dalam kategori kurang berkelanjutan yaitu 39,26 (Dimensi ekonomi) dan 41,98 (Dimensi sosial). Rekomendasi pengelolaan guna meningkatkan keberlanjutan daerah tangkapan air waduk PLTA koto panjang di Kabupaten Kampar dilakukan dengan memprioritaskan atribut-atribut sensitif pada setiap dimensi yang dikaji. Pengelolaan pada masing-masing dimensi yaitu:

a) Dimensi Ekologi. Melakukan reboisasi atau penghijauan melalui Dinas Lingkungan Hidup Kabupaten Kampar terhadap lahan-lahan yang terbuka terutama yang berdekatan dengan sungai dan melakukan pelatihan pertanian ramah lingkungan serta membentuk dan memperkuat kelembagaan kelompok tani dan masyarakat peduli api.

b) Dimensi Ekonomi. Bekerja sama dengan instansi terkait untuk mengembangkan potensi sumber daya alam seperti tempat wisata sebagai mata pencaharian alternatif untuk meningkatkan penghasilan masyarakat.

c) Dimensi Sosial. Dinas lingkungan hidup perlu meningkatkan sosialisasi dan penyuluhan kepada masyarakat yang berada di daerah tangkapan air waduk PLTA Koto panjang tentang pentingnya menjaga daerah tangkapan air

\section{Saran}

Saran dan masukan untuk penelitian keberlanjutan pada Daerah Tangkapan Air Waduk PLTA Koto panjang selanjutnya adalah:

1. Pada penelitian ini hanya menganalisis aspek ekologi, ekonomi dan sosial, berdasarkan hasil analisis dimensi ekologi yang telah dilakukan terdapat kegiatan alih fungsi lahan dan illegal logging pada lokasi penelitian sehingga perlu ditambahkan dimensi hukum dan tata kelola pada penelitian selanjutnya.

2. Penelitian ini hanya menggambarkan kondisi keberlanjutan daerah tangkapan air Waduk PLTA Koto Panjang yang berada pada desa yang berada pada kecamatan Koto Kampar Hulu dan XIII Koto Kampar, sehingga perlu dilakukan penelitian pada desa-desa lainnya yang masuk kedalam kawasan daerah tangkapan air waduk PLTA Koto Panjang.

\section{Referensi}

Adimu, H.E. 2018. Strategi Pengelolaan Kawasan Konservasi yang Efektif dan Berkelanjutan di Taman Nasional Wakatobi. [Disertasi]. Bogor : Sekolah Pascasarjana, Institut Pertanian Bogor.

Ardhana, I. 2016. Dampak Laju Deforestasi terhadap Hilangnya Keanekaragaman Hayati di Indonesia. Jurnal Metamorfosa III (2): 120-129 
Gumilar I. 2012. Partisipasi masyarakat pesisir dalam pengelolaan ekosistem hutan mangrove berkelanjutan di Kabupaten Indramayu. Jurnal Akuatika, 3(2): 198-211.

Heryani, N. dan N. Sutrisno. 2019. Perencanaan Penggunaan Lahan Daerah Tangkapan Air (DTA) Waduk Batutegi untuk Mengurangi Sedimentasi. Jurnal Sumberdaya Lahan. 6(1): 23-32

Noveliyana, Y. 2016. Pengelolaan Ekosistem Mangrove Berkelanjutan di Pesisir Kabupaten Tangerang, Provinsi Banten. [Tesis]. Bogor: Sekolah Pascasarjana, Institut Pertanian Bogor.

Nurdin, SB., Zulkarnain dan Sukendi. 2017. Analisis Indeks Penutup Lahan Daerah Tangkapan Air Waduk PLTA Koto Panjang Menggunakan Aplikasi Sistem Informasi Geografis (SIG). In Pengembangan Infrastruktur Berkelanjutan untuk Meningkatkan Daya Saing Bangsa, 3: 219-227.

Siagian, M., 2010. Strategi Pengembangan Keramba Jaring Apung Berkelanjutan di Waduk PLTA Koto Panjang Kampar Riau. Jurnal Perikanan dan Kelautan 15 (2):145-160 